\title{
Of Nails and Needles: A Reconsideration of the Political Economy of Canadian Trade ${ }^{1}$
}

\author{
Paul Kellogg Trent University²
}

\begin{abstract}
Résumé
Selon un point de vue hégémonique en économie politique au Canada, l'exportation de produits bruts dominerait le profil commercial du Canada, au détriment des produits manufacturés. La montée en flèche de la valeur des exportations d'énergie canadiennes et une forte tradition d'importation de produits finis manufacturés semble donner raison aux économistes politiques nationalistes de gauche qui brossent le portrait d'une économie où le secteur manufacturier serait sous-développé. Or, grâce à un examen empirique, le présent article remet en question certaines présuppositions répandues sur ce qui constitue une exportation de produits « manufacturés » et avance que le profil commercial du Canada concorde parfaitement avec celui d'une économie capitaliste avancée. Le nationalisme de gauche s'appuie à tort sur des catégories appropriées pour une économie dépendante, inappropriées pour le Canada. Une approche marxiste montre une économie avec un marché intérieur relativement développé, où la «création de plus-value » vise la classe capitaliste canadienne, au lieu d'en faire fi comme ce serait le cas dans une économie dépendante.
\end{abstract}

\begin{abstract}
The hegemonic view in Canadian political economy is that Canada's trade profile is weighted towards the export of unprocessed products, and away from manufactured products. With the soaring value of Canadian energy exports, combined with an import history weighted towards the import of finished manufactured goods, left nationalist political economy seems to be on strong footing painting a picture of an economy with an underdeveloped manufacturing sector. This article will empirically re-examine Canada's trade profile, question some common assumptions about what constitutes 'manufactured' exports, and argue that Canada's trade profile is perfectly compatible with that of an advanced capitalist
\end{abstract}

1 This is part of a larger research project into the political economy of Canadian trade. It is a continuation of research presented in 2005 (Kellogg, 2005a). Some of the ideas were first sketched out in my Ph.D. dissertation (Kellogg, 1991).

2 Paul Kellogg, Ph.D. (Queen's), M.A. (York) teaches in the Department of International Development Studies at Trent University. Recent publications include "Regional Integration in Latin America: Dawn of an Alternative to Neoliberalism?" (New Political Science, Vol. 29, No. 2, June 2007 pp. 187-209) and "Kari Levitt and the Long Detour of Canadian Political Economy" (Studies in Political Economy 76, Autumn, 2005, pp.31-60). He can be reached at paulkellogg@trentu.ca 


\section{Of Nails and Needles: A Reconsideration of the \\ Political Economy of Canadian Trade}

economy. Left nationalism has mistakenly relied on categories appropriate to dependent economies, categories inappropriate for Canada. A Marxist approach reveals an economy with a more or less developed 'home market' economy, where the 'self-expansion of value' is directed towards the Canadian capitalist class, not away from it, as would be expected in a dependent economy.

\section{Introduction}

Jim Stanford, one of Canada's most prominent political economists, kicked off 2007 with the rewrite of an old proposition - the image of Canada as a hewer of wood and a drawer of water. By 1999, he said, with a steady rise of manufacturing exports, the Canadian economy seemed to have escaped this fate, long the expected curse of an over-reliance on natural resource development (2007: A13). But the reprieve proved short-lived. With tar sands development beginning to dominate economic expansion, Canada was now a 'hewer of wood and a pumper of oil'. Stanford's clever rewriting of the old proposition was based on one of the most important, and most enduring, methods for assessing Canadian economic development - measuring "the proportion of Canadian exports that consists of finished goods, rather than unprocessed or partially-processed resources" (2007: A13). Stanford's proposition is, that with the rapid rise of energy, especially tar-sands based oil exports, Canada's economic structure is regressing.

Stanford's analysis is strongly grounded in the Canadian political economy tradition. Central to this tradition is the very proposition advanced by Stanford - that the structure and composition of foreign trade is an important indicator of the level of a country's economic development. The classic statement of this thesis was in Glen Williams' oftreprinted Not for Export (Williams, 1994; Williams, 1986). Roughly put - consistently high levels of exports of agricultural products and crude materials combined with consistently high levels of imports of finished, manufactured end products, can be seen as a sign of economic underdevelopment.

This article will argue that while this is, in a very general sense, a reasonable proposition - it has been consistently misapplied to the Canadian economy. The article will: 1) survey the way in which assumptions about resource trade figure prominently in contemporary assessments of Canada's level of economic development; 2) look behind the prima facie case for linking Canada's trade structure to the economy's 'underdevelopment'; 3) examine the controversy over the role of the auto sector in assessing Canadian trade statistics, 4) look in-depth at the peculiar, and misunderstood category, Fabricated Materials: Inedible; and finally, 5) interrogate the post-1999 rise in crude material export, and see if it really is a sign of manufacturing regression. Throughout, the article will argue that fundamental to the confusion surrounding the analysis of Canadian trade has been the mistaken assumption that categories appropriate to dependent economies can be used in the Canadian context. 


\section{Of Nails and Needles: A Reconsideration of the \\ Political Economy of Canadian Trade}

This has proven to be false. If one of the difficulties faced by dependent economies is the difficulty of establishing a home market - a self-sustaining regime of capital accumulation - this has not been one of the difficulties faced by Canada since the establishment of a home-market economy in the mid-19th century.

\section{Trade and Canadian Political Economy}

Most political economists of the left have seen trade as the Achilles heel of the Canadian economy. Canada is unusually dependent on the export trade in general, it is argued, and the export of raw materials in particular. One of the great resources for students of political economy in Canada has been a series of compilations, beginning with the 1978 A Practical Guide to Canadian Political Economy (Clement and Drache, 1978), and continuing into this century with Changing Canada: Political Economy as Transformation (Clement and Vosko, 2003). The 1997 edition contained a serious restatement of the political economy approach to Canadian development, where this view of the importance of Canada's trade structure was given pride of place.

[T] he Canadian economy has never acquired the authentic attributes of a bona fide national economy. Rather, in this century, and as far back as the initial European colonization, Canada's economy has been a subordinate adjunct or satellite, of more developed economies.... TThis view is grounded in three considerations: unmatched levels of FDI and foreign control of production; the resource-extraction base of foreign trade; and the branch-plant organization of manufacturing by parent U.S. industries (Clement and Williams, 1997: 60).

Glen Williams more than anyone has given theoretical shape to this line of reasoning in his widely read and quite influential Not For Export. The 1980's edition was rightly included by Drache and Clement as one of the thirty-three 'staple readings' in Canadian political economy, one of those key works which has contributed much to the literature (Drache and Clement, 1985: 227-29). The 1990's edition became a staple in its own right in reading lists for courses on Canadian political economy. In this work, Williams cited an economic proposition that "high exports of finished manufactures indicate high levels of industrialization" (Williams, 1986: 8) and showed that even in 1980, Canada's relatively low levels of manufactured exports raised questions about Canada's degree of industrial development. In 1955, by his figures, Canada's exports of finished manufactures as a share of total exports was $11 \%$, while only Sweden and France were significantly below $50 \%$ (each above one-third, however) of eight industrial countries (the OECD Group of Seven, plus Sweden). By 1980, Canada was up to $32 \%$, but now all the other seven countries were above $50 \%$, and manifestly underdeveloped India at was at $23 \%$ and Brazil at 22\%, not far off the Canadian figure (Williams, 1986: 8-9). 
From the 1986 edition to the 1994 edition, Williams' analysis underwent an important evolution. Between the two editions was an influential 1988 article, where Williams grappled with the issue of Canada's place in the world economy. He rejected both the classical dependency framework and the 'advanced imperialist' school represented in particular by David McNally (1981) and William Carroll (1985). As an alternative, he argued that Canada should be seen as a "region within the centre" (Williams, 1988: 136). This evolution in his thinking was reflected in changes made to the 1990's edition of Not for Export. The earlier edition was called, Not for Export: Toward a Political Economy of Canada's Arrested Industrialization. The 1994 edition was called Not For Export: The International Competitiveness of Canadian Manufacturing. "[I]t could be debated" Williams says in the 1986 edition "whether Canada more properly belongs among the semi-industrials" (Williams, 1986: 8-9). But that section is gone from the 1990's edition. It is worth quoting at length the new material inserted in its place.

[Political economist Alfred] Maizels ... debated the appropriate category in which to place Canada. Important to his choice were the relatively high value of Canada's per capita production and also the relatively high proportion of our semi-processed but nonetheless manufactured exports....In the end ... Maizels decided to place Canada among the industrials (Williams, 1994: 21).

The evolution in Williams' thinking is important, and the points he tentatively highlights here will loom large in the discussion below.

\section{The Prima Facie Empirical Case}

Empirically, there was apparently a basis for Williams' 1986 argument from the standpoint of the 1950s and 1960s. Chart 1 documents the trajectory of Canadian end product (finished manufactures) exports as a percent of all exports from 1946 to 1961. Canada's percentage share of end product exports is nowhere near the $50 \%$ mark documented by Williams as typical of advanced capitalist countries. It sits at just $15 \%$ in 1946, slides to just above $6 \%$ in 1955 , and creeps back to just above the $8 \%$ mark in 1961 . These are, in fact, extremely low figures. 
Political Economy of Canadian Trade

Chart 1: End Product Exports as a Percent of all Exports, Canada, 1946-1961

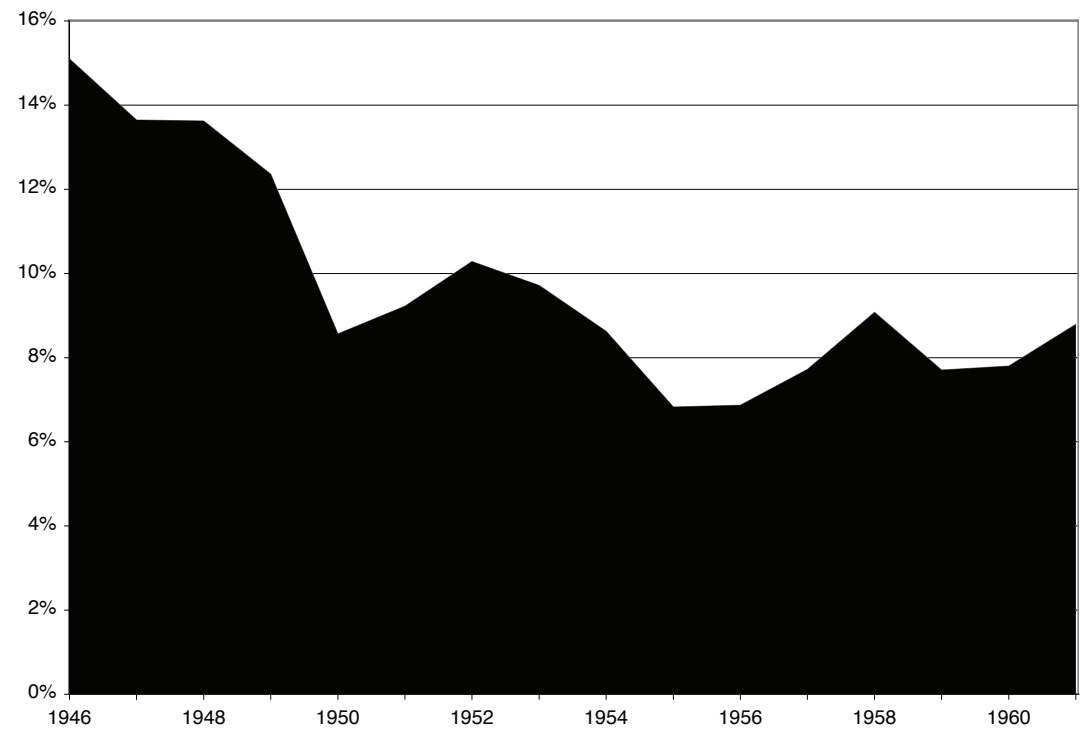

(Leacy, 1982: Series G415-G442; Statistics Canada, Dec. 1978; 1981;1984; Statistics Canada, Dec. 1986; Dec. 1988; CANSIM II, Table 228003)

But in the decades since, this trend has been entirely reversed. Chart 2 takes this method (expressing end product exports as a percent of all exports) and extends it into the present. The results speak for themselves. 


\section{Chart 2: End Product Exports as a Percent of all Exports, Canada, 1946-2006}

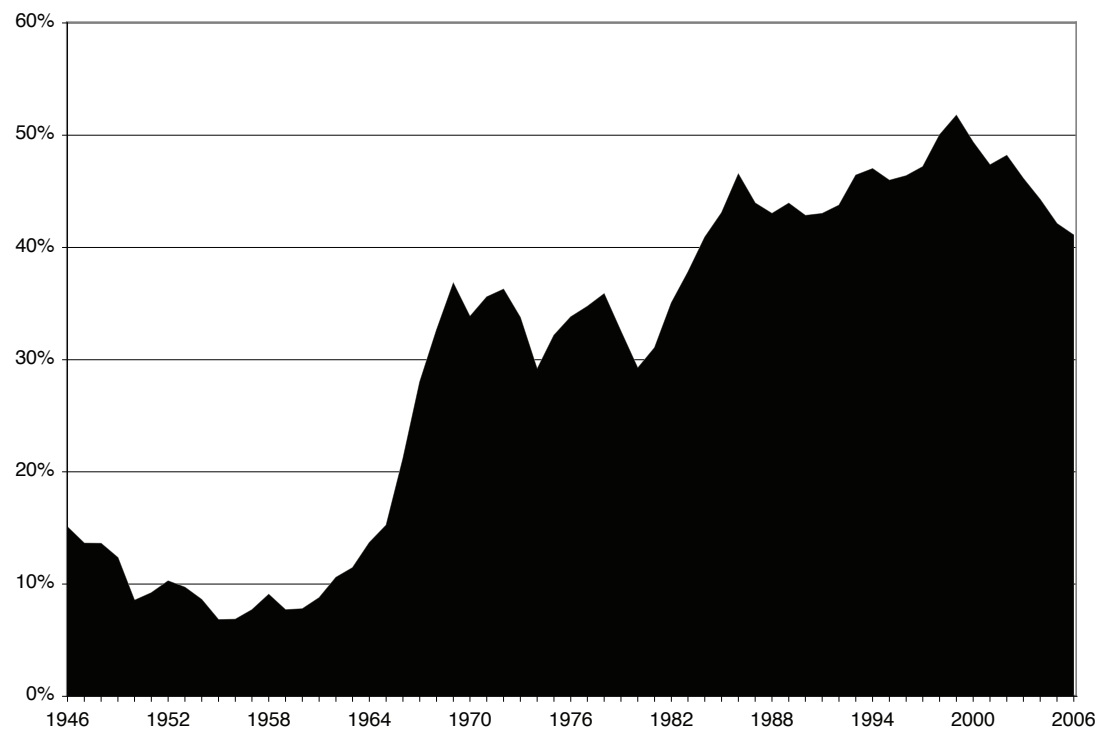

(Leacy, 1982: Series G415-G442; Statistics Canada, Dec. 1978; 1981; 1984; Statistics Canada, Dec. 1986; Dec. 1988; CANSIM II, Table 22803)

From the early 1960s on, end product exports as a percent of all exports rise from below $10 \%$, to between 30 and $40 \%$ in the 1970 s, and then between 40 and $50 \%$ from the mid 1980 s to the present. This is, by Williams' own criteria, the trade profile of a fully industrialized country. ${ }^{3}$ There is, however, a pronounced decline from 1999 to 2006 , evidence cited by Stanford earlier in this article to document a slide back into underdevelopment. This aspect of the data will be dealt with in the final section of this article.

What of the other half of the proposition - that of a reliance on high levels of imported finished manufactured goods? Williams makes a good deal of this point, basing his paradigm, on Alfred Maizels, an authority who will loom large in these pages.

As a corollary of his proposition that high exports of finished manufactures indicate high levels of industrialization, Maizels suggested that the larger industrial countries

3 There is also a prima facie case for the left nationalist and new political economy assumptions when it comes to foreign ownership, although the periodization is somewhat different. Through the 1950s and into the early 1970s, there is statistical evidence that could be cited as proof of unusually high levels of foreign ownership. But there is an enormous change in the opposite direction through the 1970s, 1980s and early 1990s. A brief return to increasing levels of foreign ownership occurred in the mid to late 1990s, but was soon followed in the 21 st century by a renewed change away from the expected trajectory implicit in the dependent Canada assumptions (Kellogg, 2005b). 


\section{Of Nails and Needles: A Reconsideration of the \\ Political Economy of Canadian Trade}

were less dependent on imports of manufactures than the smaller industrials, semiindustrials, and non-industrials (Williams, 1994: 19-20).

A useful device for highlighting this is to express end product exports as a percent of end product imports. The lower the figure, the greater the gap between end product exports and end product imports, the greater the 'dependency' of the economy on end products manufactured abroad. Chart 3 documents this for the same period as Chart 1 , and if anything, the picture that emerges is even stronger than that outlined in Chart 1. In 1946, Canadian end product manufacturing exports were just half the figure of end product imports. By 1956, this had declined to just $10 \%$. This is an extraordinary figure. It paints a picture of an economy where masses of finished manufacturing goods are pouring in across the border, far out of proportion to the export of manufacturing goods being exported abroad, once again reinforcing Williams' thesis.

\section{Chart 3: End Product Exports as a Percent of End Product Imports, Canada,} 1946-1961

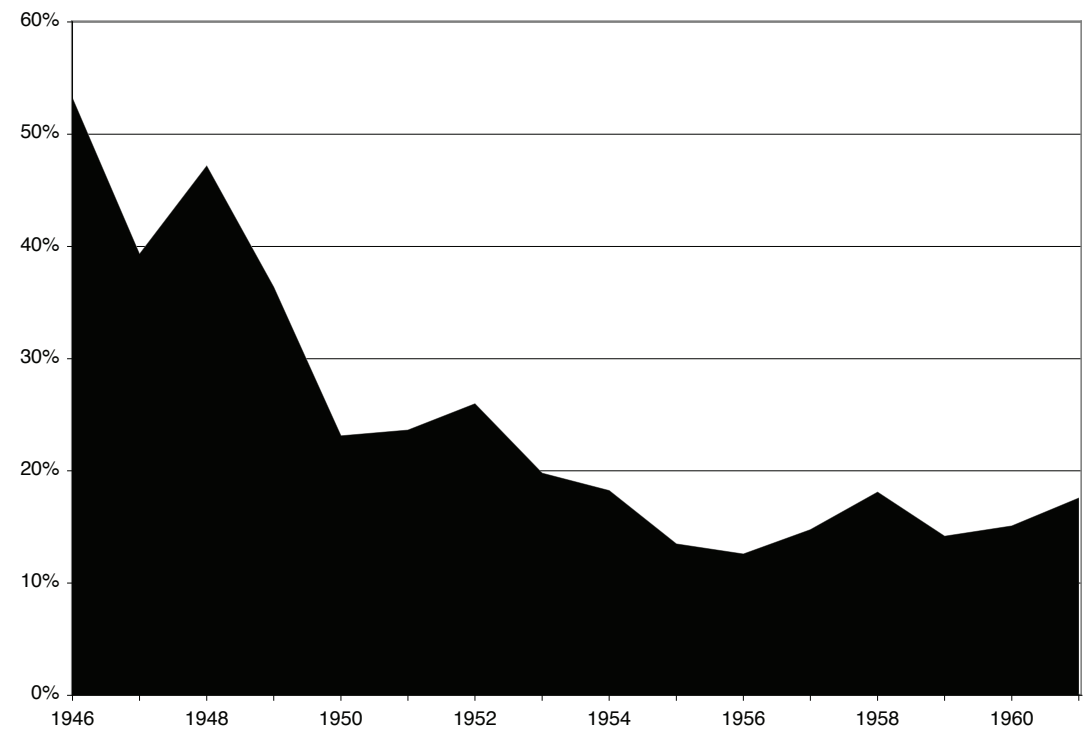

(Leacy, 1982: Series G415-G442; Statistics Canada, Dec. 1978; 1981; 1984; Statistics Canada, Dec. 1986; Dec. 1988; CANSIM II, Table 22803)

But Chart 4 extends the time frame to 2006, and again, the picture is completely reversed. The picture painted is actually quite revealing. By the 1970s, the figure rises from just over $10 \%$ to between 50 and $60 \%$. By the 1990 s and into the 21 st century, the figure rises again 
to between 70 and $85 \%$. In other words, over time, Canada's capacity to export end products is growing more quickly than its need to import end products. There is still a gap between the two. Canada still imports more end products than it exports - but presumably this is only relevant if it is a sign of an ongoing structural underdevelopment of manufacturing in the country. If end product exports are growing faster than end product imports, such an underdevelopment cannot be demonstrated.

Chart 4: End Product Exports as a Percent of End Product Imports, Canada, 1946-2006

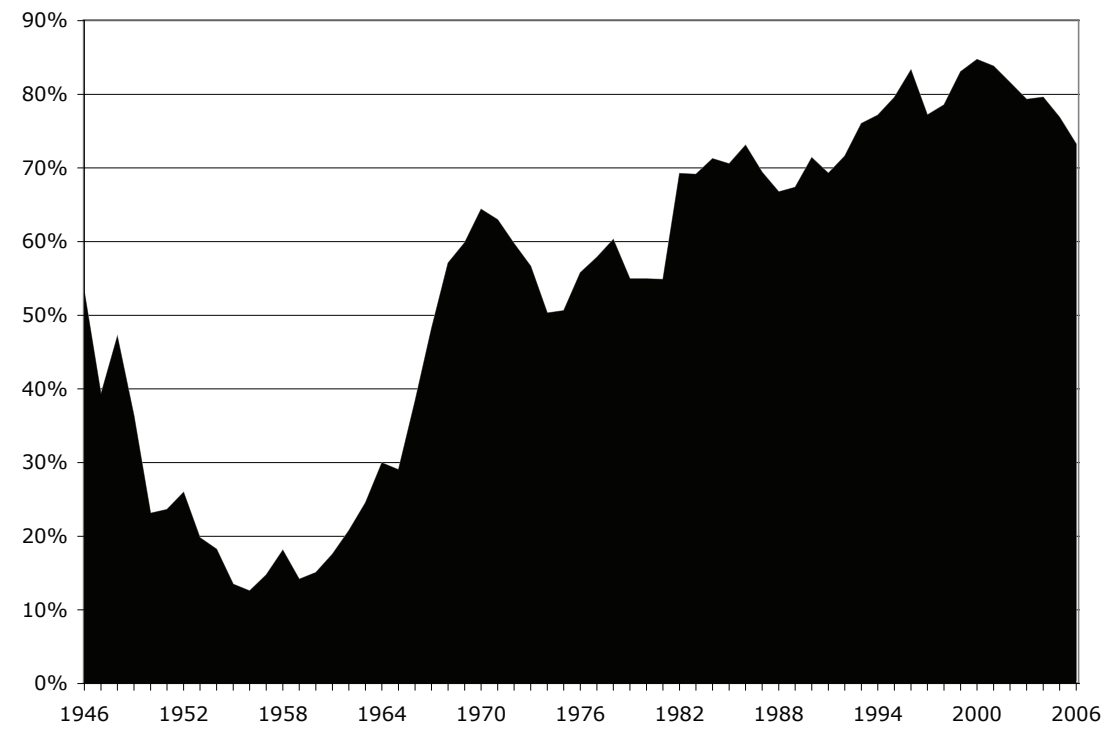

(Leacy, 1982: Series G415-G442; Statistics Canada, Dec. 1978; 1981; 1984; Statistics Canada, Dec. 1986; Dec. 1988; CANSIM II, Table 22803)

At the very least, it is necessary to severely temper the claims made by Williams and others. Yes an imbalance exists; no it has not prevented the development of a powerful Canadian manufacturing sector (a finished manufacturing sector). And that imbalance is today, far less than it was half a century ago. The trend is very clear.

The impact of a negative balance in the trade of finished manufactures is quite different in an advanced capitalist country like Canada, than in an underdeveloped economy in Latin America or Africa (Kellogg, 2005b: 49-51). In the latter, such a 'technological dependence' could well be a barrier to economic development. But in an advanced capitalist country, particularly one of relatively small population such as Canada, the existence of high levels 


\section{Of Nails and Needles: A Reconsideration of the \\ Political Economy of Canadian Trade}

of importation of foreign machinery is not unusual. Once again it is Maizels who makes precisely this point.

Unlike the effect on exports, the effect of industrialization on the proportion of imports consisting of manufactures varies considerably from country to country and from one period to another. This is because the import pattern of an industrializing country is heavily dependent on its resource-endowment, as well as on its developing pattern of demand....[D]ifferent tendencies among the industrial countries reflect the fact that the smaller countries inevitably tend to specialize, while the larger ones produce virtually the whole range of manufactured goods. Thus, the smaller industrial countries depend heavily on the larger ones for increases in their requirement of manufactures, so that as their economies expand the proportion of manufactures in their total imports tends to rise (1963: 66-67).

\section{The Auto Pact Effect}

This is why, again and again, auto industry statistics take centre stage in arguments about Canada's industrial structure. Unless statistics on auto exports are deliberately excluded, no case can be made about Canada having a 'truncated' or 'undeveloped' manufacturing sector. Williams points out that the largest single component of Canada's manufactured exports are vehicles covered by the Auto Pact, and that these are 'intra-firm transfers'. If they are excluded, then Canada's share of manufactured exports drops to $22 \%$ in 1980 . "This leaves us squarely in the company of Brazil and India" (Williams, 1986: 10).

The exclusion of Auto Pact trade is fairly common among Canadian political economists. I have looked at this argument in detail elsewhere (Kellogg, 2003; 2004) challenging this now well-established practice of analyzing the Canadian economy as if the auto sector did not exist. If the argument was that the branch plant nature of this production made it temporary and impermanent, then that impermanence is now two or three generations old. If the argument was that the branch plant nature of this production would ensure U.S. dominance in the sector, then the steady expansion of Toyota, Nissan and other non-U.S. auto producers cannot be explained - nor can the emergence of Franch Stronach's very Canadian Magna Corporation as the dominant auto parts producer in the entire sector. ${ }^{4}$

For the purposes of this article, two charts will be provided - and the readers can draw their own conclusion. Chart 5 shows the composition of all exports, from 1961 to 2006. The trend is clear and unmistakable - the export of end products (finished manufactured

4 This latter fact is extremely ironic. Fear of dependency on U.S. corporations led many on the left in the 1960s to advocate the creation of an all-Canadian car (Anastakis, 2004: 109). As Stronach moves closer to being able to move from a parts-maker to full assembly, we are on the verge of getting just such a creature. It is not clear what we would celebrate however - Magna being one of the more avaricious and union-busting companies operating in Canada (Gindin, 2007). 
products) takes up a greater and greater share of all Canadian exports, moving from roughly $10 \%$ in 1961 , to roughly $50 \%$ in recent years.

\section{Chart 5: Composition of Exports, Canada, 1961-2006}

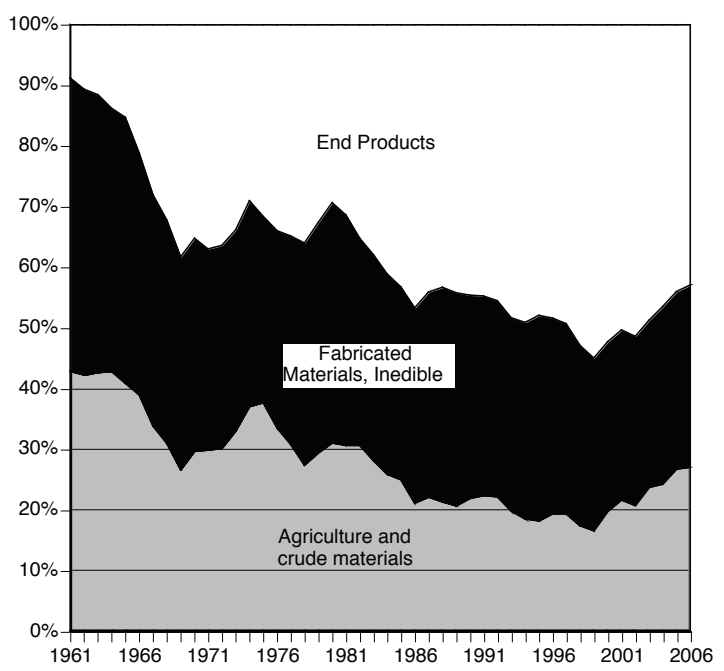

(Dominion Bureau of Statistics, External Trade Branch, January 1947;December 19471961; Dominion Bureau of Statistics, External Trade Branch, January 1962; December 1965-1971; Statistics Canada, External Trade Division, December 1974; Statistics Canada, External Trade Division, December 1975-1984; CANSIM II, Table 228003.)

Chart 6 draws the same picture, but excluding auto and truck assembly, and auto and truck parts manufacture. The resulting picture is different, but not qualitatively. Finished manufacture exports in 1961 are less than $10 \%$ of all exports. That figure then rises steadily, until in recent years, it sits between 30 and $45 \%$. Now this is less than the percentages which include the auto sector. But the critical issue is the trend - and without question, the long-term trend over three generations is for a steady increase in the proportion of trade devoted to finished manufactured goods. 


\section{Of Nails and Needles: A Reconsideration of the \\ Political Economy of Canadian Trade}

\section{Chart 6: Composition of Exports (excluding autos and trucks), Canada, 1961-2006}

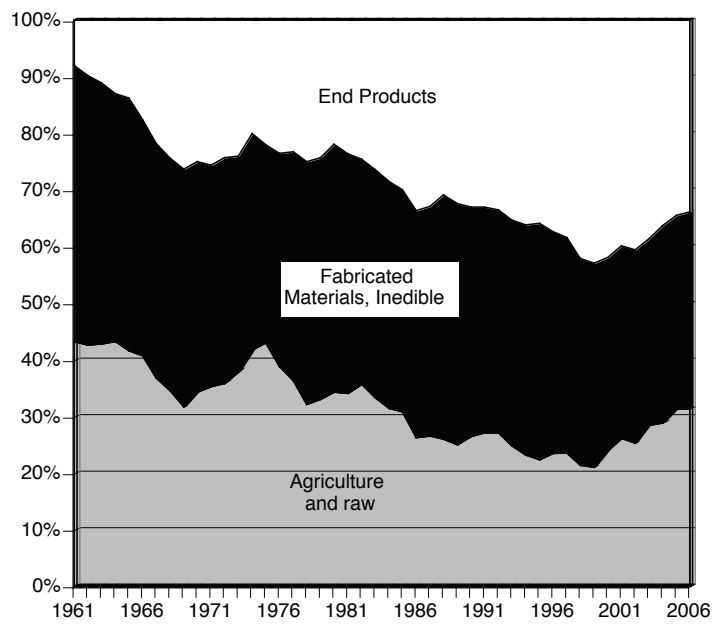

(Dominion Bureau of Statistics, External Trade Branch, January 1947, December 19471961; Dominion Bureau of Statistics, External Trade Branch, January 1962, December 1965-1971; Statistics Canada, External Trade Division, December 1974; Statistics Canada, External Trade Division, December 1975-1984; CANSIM II, Table 228003.)

The claim that has been aggressively advanced by most of the theorists within the school of new political economy, is that Canada has a long-term structural weakness in end products export trade. Once the actual figures are examined, no such claim can be made. The most that can be asserted is that through the 1950s, Canada's share of exports which were finished manufactures was lower than the norm for other advanced capitalist countries, considerably lower. But from 1961 to the present, there has been a dramatic rise in finished manufacturing exports, even with the 'Auto Pact Effect' as outlined by Williams. With the Auto Pact Effect, the rate of growth is the same, but there is still 10 to $15 \%$ to be made up. Without the Auto Pact Effect, Canada has reached a level of finished manufacture exports equivalent to other advanced capitalist economies. So perhaps an argument could be developed about a somewhat weaker position based on somewhat lower rates of finished manufacture export. But this is a much weaker argument than that maintained throughout the new political economy literature. Even if the claims involved in Williams' Auto Pact Effect argument are accepted, the statistics simply do not bear out the extreme claims about truncated manufacturing and industrial weakness made on the basis of this effect by Williams and many others. 
Which, of course, begs the question as to why it should be seen as acceptable to exclude intra-firm transfers as Williams proposes. Now all statistics have to be kept in perspective, and they are indeed only one of many available windows into the workings of an economy. Like all windows, they are sometimes more and sometimes less obscure, but like all they do tell something about what happens in that economy. To say that the window on auto trade tells nothing about the Canadian economy (which is in fact what is being argued), is to pretend that it simply doesn't exist. But in the real world, its existence is palpable. The existence of autos to export (even as intra-firm transfers) implies the existence of an auto industry. The 172,000 Canadians who worked building car and trucks in Canada in 2001 - a higher per capita proportion than in the U.S. (Aerospace and Automotive Branch, Industry Canada: 52) - are in one of the largest per capita auto-producing economies in the world (International Organization of Motor Vehicle Manufacturers). Oshawa, site of origin of many of these intra-firm transfers, is one of North America's most productive vehicle production centres (Ministry of Economic Development and Trade, 2003). Ontario, in 2005, surpassed Michigan as the biggest centre in North America for vehicle production - much to the chagrin of many in the U.S. (Hoffman, 2005). Just-In-Time delivery schedules and Canada's role in what is emerging as a world division of labour in automobile production are promoting the growth of Canadian-based car parts manufacturers, propelling Frank Stronach's Magna to the very pinnacle of the auto parts heap (Gindin, 2007).

The point is, that trade figures are indicators of economic activity. "[I]ncreasingly, international trade occurs between related parties especially international firms and their affiliates" (Macdonald, 1985: 242). To single out Canadian auto trade as the only chunk of world manufacturing trade to be written out of a statistical comparison with other actors in the world economy - which all have small and large chunks of trade in the form of intra-firm transfers - is not tenable.

One final point needs to be made. Canada is one of the world's leaders in its total volume of trade. A small percentage of manufacturing trade for Canada actually conceals a quite high total volume of manufacturing trade, given the fact that it imports and exports at a per capita rate that is three times that of the U.S. (Kellogg, 2005: 44-45).

The conclusion seems relatively straightforward. The facts presented here do not conform to the picture of Canada as a semi-industrial, let alone an underdeveloped economy. They do fit very well with the picture of Canada as a first-world, advanced capitalist economy, where the self-expansion of value is resulting in an expanding capacity to export fully manufactured goods abroad. 


\section{Of Nails and Needles: A Reconsideration of the \\ Political Economy of Canadian Trade}

\section{Of Nails and Needles - Fabricated Materials (Inedible)}

If the difficulty with Williams' argument is the fact that it excludes the manufacturing activity of Windsor and Oshawa from a conceptual picture of Canada's industrial structure, it is necessary to highlight the fact that the statistics that are being used here already eliminate Hamilton and its massive steel mills, as well as much of Cornwall, Sudbury, Sarnia and British Columbia from that same picture. An examination of the raw figures that went into creating Chart 5 (above) is quite revealing. From a very low point of $9 \%$ of total trade, 'end products inedible' steadily grow as a proportion of total Canadian exports, peaking at $55 \%$ in 1999 , and being steadily above $40 \%$ since 1984 . But the remaining exports are not the raw materials and primary products that much of the new political economy literature implies. In 1961, for instance, the biggest single category of Canadian export was 'Fabricated Materials, Inedible' with a 48\% share of total exports. From 1961 until 1968 Fabricated Materials, Inedible comprised the biggest category of Canadian exports. From 1968 on it retreats, to second place (behind end product exports) but still stays above the exports of crude materials and agricultural products (See Chart 5). When this category is interrogated, it becomes clear that this very large category of Canadian exports is an extremely heterogeneous one, grouping together products as diverse as yarn and railway tracks.

This is not a small matter. One of its biggest sub-categories is chemicals. Here are included such capital-intensive manufacturing activities as synthetic rubber and plastic materials production. Iron and steel is another sub-category, including such manufacturing products as bars and rods, steel sheets and steel plates and railway track material (hence the reference to Hamilton). The biggest sub-category is wood and paper, incorporating products from all Canadian sawmills and all pulp and paper plants. That provides a clearer basis for interpreting Charts 5 and 6 . The point is, much of what is included in the fabricated materials section of the charts is capital-intensive manufacturing - even if the result is not, strictly speaking, an end product. And in both - including the one which excludes the auto sector - a clear picture is presented of a relentless transformation in Canada's export profile, away from a reliance on the export of agricultural goods and raw materials, and towards a reliance on fully-manufactured and semi-manufactured goods.

Even as early as 1961 when the proportion of Canadian exports going towards finished manufactures was quite low, still a majority of Canada's exports was comprised of products that were in some way subject to manufacturing processes - perhaps a hewer of wood, but with the assistance of giant tractors and large factories: perhaps a drawer of water, but through an intricate system of dams and hydraulic lift systems. Second, there has been a relentless increase of finished manufacturing exports at the expense of the share of export going towards fabricated, or semi-manufactured products. Third and probably most importantly, there has been an even more impressive increase of both categories together, 
squeezing the share of agricultural and crude material exports into a smaller and smaller area of the chart. That steadily declining portion of the graph, to complete the metaphor that is here being stretched, is a representation of the place of the agricultural economy of the Prairies, the Atlantic Fisheries and the Niagara fruit belt in the Canadian economy. Their place is steadily declining relative to the other two categories. This is not a picture of an economy caught in a staple trap, unable to break from a reliance on raw material, resource export, unable to develop a manufacturing potential.

No image dominates the new political economy literature as much as this picture of Canada's truncated manufacturing sector. And this has been one of the most powerful buttresses of the image, statistical pictures showing low percentage levels of finished manufacturing exports. Williams puts the case well.

\begin{abstract}
Industrialization is said to be associated with economic development because it leads to increases in both labour productivity and real incomes. In turn, relative levels of industrialization and worldwide industrial competitive power can be measured through manufactured exports because industrial growth enhances trade potential. This accounts for the 'remarkably close relationship over the past 60 years in the relative growth rates of the main industrial countries and their shares of the world export market in manufactures' (Williams, 1986: 7).
\end{abstract}

The authority Williams is quoting is, again, Alfred Maizels (1963: 57), but it is interesting to note that, as it concerned Canada, Maizels work does not draw the same conclusions as Williams did in 1986. Maizels does note that Canada in the 1950s has a low share of its exports that can be classified as finished manufactures. But Maizels has other criteria that are crucially important in categorizing the place of economies in the world system. One extremely important one is the productivity of manufacturing employment, the dollarvalue of production manufactures per head. Canada might have had a low level of finished manufacturing export, but it was second only to the United States in manufacturing productivity. In 1955, the U.S. was first at $\$ 5730$ of production per employed manufacturing worker, Canada was second at $\$ 4380$ and Sweden was a distant third at $\$ 3050$ (Maizels, 1963: 31). Maizels pays careful attention to the Canadian case when categorizing the world into industrial countries and semi-industrials. He documents that an examination of the raw statistics reveals that Canada's share of finished manufacturing export is incredibly low compared to the United States and Western Europe. He argues that on the basis of these statistics, 'Canada falls between' the industrially advanced countries of Western Europe and the United States and a second group of countries where exports of finished manufactures accounted for under $15 \%$ of their total exports (such as Australia). However, he argues: 


\section{Of Nails and Needles: A Reconsideration of the \\ Political Economy of Canadian Trade}

[I]n export structure Canada is, in fact, much more like Norway, Sweden and Holland than she is like Australia. One-half of Canada's exports are industrial products (even though most are intermediates) ... Further the degree of industrialization in the Canadian economy is significantly greater than in Australia, while Canadian productivity in manufacturing is second only to that in the United States. A final consideration is the very close inter-relation that has developed, particularly during and since the last war, between the Canadian economy and that of the United States. In many respects, the two countries can effectively be regarded as a single economic system, and they are likely to grow closer together in the future as their economies expand. For this reason, as much as for the others, it was decided to classify Canada in the same broad grouping as the United States (Maizels, 1962: 60-2).

If this conclusion could be drawn in the mid 1950s on the basis of a very low share of manufacturing export, in 21st century, there is no question what conclusion should be drawn.

Since Maizels wrote his text, there have been quantitative but not qualitative changes in this picture. Chart 7 tracks the value of manufacturing production, per manufacturing worker, in Canada and the U.S., from 1970 through 2006. Until the late 1980s, productivity in the manufacturing sector (measured as value-added per manufacturing worker) is almost identical. There is a divergence visible in the 1990s, with US productivity growing consistently faster than Canadian. 
Chart 7: Production per manufacturing worker (1990 U.S. dollars), Canada and the U.S., 1970-2006

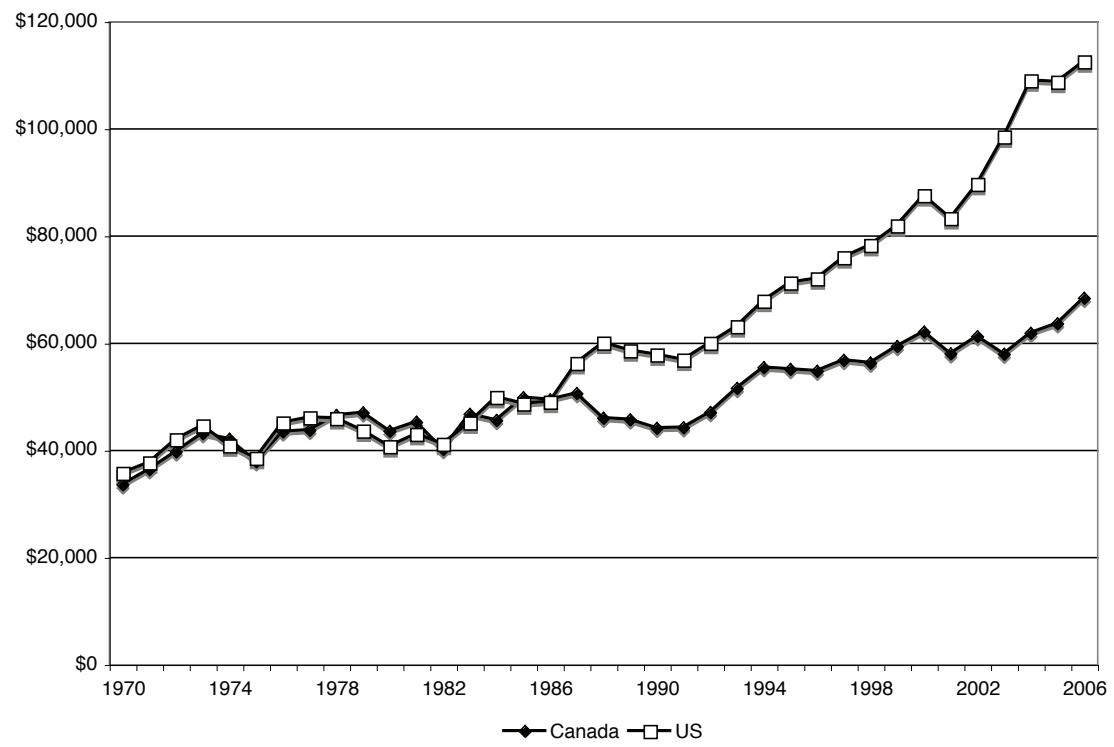

(Bureau of Labor Statistics; CANSIM II Table 228003; United Nations Statistics Division)

But when other factors are brought into consideration, it seems probable that this divergence in manufacturing productivity has more to do with employment and lay-off patterns in the two countries. Chart 8 shows the history of per-capita manufacturing employment in the two countries for the same time-frame. 
Chart 8: Production per manufacturing worker (1990 U.S. dollars), Canada and the U.S., 1970-2006

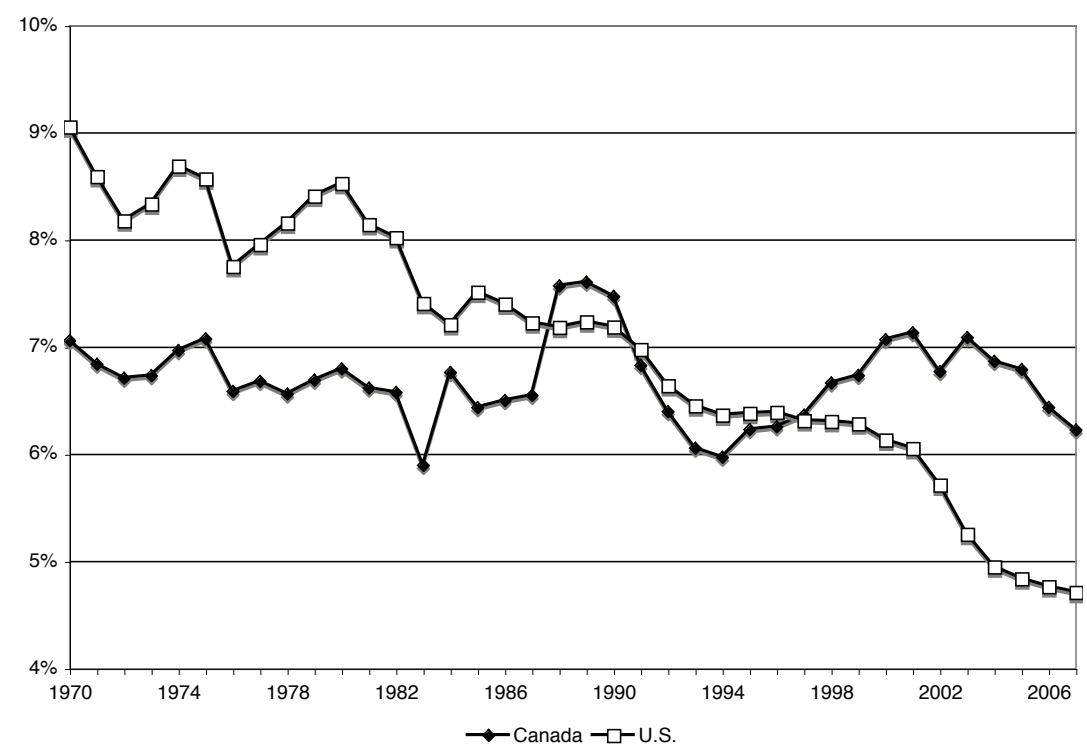

(Bureau of Labor Statistics; CANSIM II Table 228003; United Nations Statistics Division; U.S. Census Bureau)

In 1970, manufacturing employment in the U.S. represented 9\% of its entire population, Canada trailing with a figure of $7 \%$. But in the ensuing years, manufacturing employment in the U.S. has fallen drastically, so that by 2006, it represented just over $4.5 \%$ of the population. That is, in per capita terms, there were almost $50 \%$ fewer manufacturing workers in the U.S. in 2006 than in 1970. Canada's history is quite different, per capita manufacturing employment staying between $6 \%$ and $7.5 \%$ for the entire period. Far more manufacturing layoffs have happened in the U.S. than in Canada. In eliminating lowerproductivity jobs, productivity figures in the U.S. do look better than in Canada - but that reflects more productive downsizing, not more productive manufacturing.

It is always important for political economists to peer behind the categories as provided by the statistical gathering machines of the state apparatus. A quick look at Canadian manufacturing export statistics can seem to paint a picture of a semi-industrial country. But, as has been shown, a more detailed and careful examination gives exactly the opposite picture. The big winner over the last 50 years in the Canadian export trade has been the export of finished manufactures. This is true even if you arbitrarily exclude the export of 
goods through the Auto Pact (and, as has been argued, there is no plausible reason for so doing). The big loser has been the export of agricultural products and crude materials. Fabricated materials, which at first blush represent semi-manufactured goods and could be used as an argument for categorizing Canada as a 'semi-industrial' country hold their own, but slowly decline relative to the export of completely manufactured products.

\section{Dominion Bureau of Statistics: Fabricated Statistics, Incredible}

If we further interrogate the category 'Fabricated Materials Inedible', the argument being presented here is again strengthened. It is pretty clear from reading through the relevant background papers, that the civil servants who adopted the category 'Fabricated Materials, Inedible' were not thinking of the question of aiding political economists in the task of classifying Canada's place in the world system. Had they had this task in mind, they would have done better to name their effort 'Fabricated Statistics, Incredible'. They did not divide export products solely on the basis of the extent of manufacturing these products contained. Sometimes it is unclear as to what they had in mind. The new classification came into effect in 1961 and it was certainly an advance on the 1950's categories. But if the state moved two steps forward by, for the first time, separating out manufacturing exports from the gross statistics on export trade, it took one step backward by creating an extremely confusing middle category. The background paper to the new classification presents the case this way:

Section IV, Fabricated Materials, Inedible, contains all commodities which have passed the preliminary stages of processing but which are still used chiefly as materials in some later industrial process (Dominion Bureau of Statistics, International Trade Division, External Trade Section, 1961: 4).

Read this way, it would be safe to designate all products in this category as semimanufactured goods, and conclude that a heavy concentration on their export was evidence of the underdevelopment of key sectors of Canadian finished manufacturing. But the document goes on to say, however, that

Some commodities in this Section are highly processed and the chief part of their value may be derived from manufacturing (Dominion Bureau of Statistics, International Trade Division, External Trade Section, 1961: 4).

And now the issue has become quite confused. The chief merit of investigating shares of export trade by percentage of items that are manufactured, semi-manufactured and nonmanufactured is to provide a window into the extent of development (understood as the extent of industrialization) of a particular economy. But if the single biggest category of these statistics is so all inclusive that it lumps together some products which are virtually 


\section{Of Nails and Needles: A Reconsideration of the \\ Political Economy of Canadian Trade}

raw materials and others which are 'highly processed', 'the chief part of their value' being derived from manufacturing, then there is a problem. This very large statistical category conceals within itself much of the manufacturing life of what is really a very developed industrial economy.

Consider the range of goods that are included in this category:

Examples of the commodities included in this Section are dressed furs, vegetable oils, rubber belting, lumber, plywood, millwork, pulp and paper, textile yarns and piece goods, chemicals, fertilizers, plastics and synthetic rubber, metal ingots, sheets, pipe, wire and hardware (Dominion Bureau of Statistics, International Trade Division, External Trade Section, 1961: 4).

There is a world of difference between an economy based on the production of dressed furs and an economy based on the production of synthetic rubber and metal sheets. Further attempts at elaborating their definition are even more unhelpful.

The distinction between fabricated materials and end products is perhaps the greatest innovation embodied in this classification, but the principles underlying this distinction can be illustrated by considering the difference between a nail and a needle. The nail is of no use by itself; it becomes useful only in connection with other materials and then it has lost its identity as a nail by being incorporated with those other materials into something quite different from any of them. The needle, on the other hand, is used with other materials but emerges from that use still a needle which is useful again for the same purpose. In this sense the nail is a fabricated material and the needle an end product (Dominion Bureau of Statistics, International Trade Division, External Trade Section, 1961: 4).

This is completely unhelpful. An economy based on factories producing needles would show up as a highly industrialized first world economy. An economy based on factories producing nails would show up as, at best, a semi-industrial second-tier nation, and perhaps even a Third World nation. Clearly, scholars working with the results of these laboured efforts have to take the resulting statistics with a very large grain of salt.

\section{The Oil and Gas Effect}

If the trend since 1961 is relatively straightforward - a steady increase in the proportion of exports that are fully-manufactured - an examination of both Charts 5 and 6 does show a reversal of this trend in the 21st century. By the end of the 20th century, the export of finished manufactures had for the first time, crossed the $50 \%$ mark. But since then it has fallen back by about $10 \%$, and there has been a corresponding increase in the export of 
goods from the agricultural and crude materials sector. Stanford's case, that Canada is reverting to a "hewer of wood and a pumper of oil" (2007: A13) is based on these statistics, seeing in them confirmation of the underdevelopment implicit in Canada's dependent economic structure.

But before such conclusions are drawn, it is important to, this time, interrogate the categories involved. What is affecting this picture is the rapid rise of a category combining agriculture and crude materials, and the increase in the 21 st century is very much in the latter - crude materials. Like its cousin, 'Fabricated Materials, Inedible', the category is extremely heterogeneous. Chart 9 shows that it is the export of oil and natural gas which are entirely responsible for the increase in the share of 'primary' products in Canada's export profile.

Chart 9: Oil and Gas Exports as a Percent of Agricultural and Crude Material Exports, Canada, 1986-2006

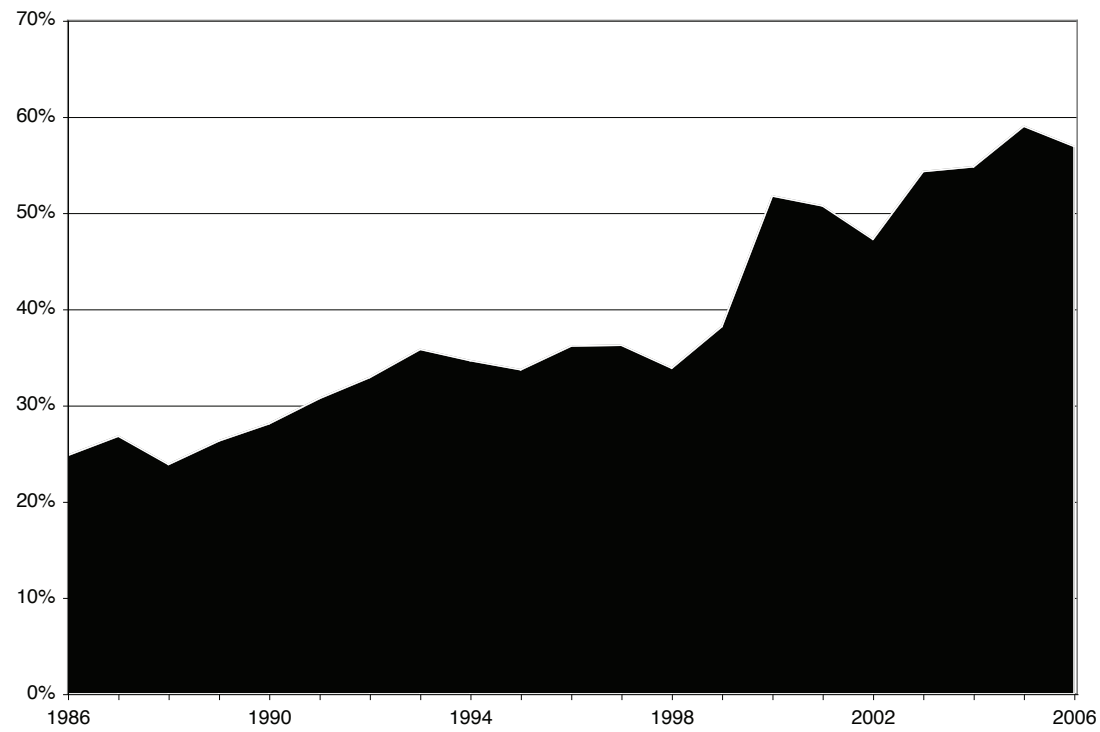

(CANSIM II, Table 228003)

In 1986, 25\% of Canada's primary export products were from the oil and gas sector. By 1999, this was just under 40\%. In 2005 and 2006, it had exploded to almost 60\%.

Now - this makes questionable Stanford's replacing 'drawer of water' with 'pumper of oil'. It is common knowledge that the centre of this boom in oil and gas production is Northern 


\section{Of Nails and Needles: A Reconsideration of the \\ Political Economy of Canadian Trade}

Alberta, and at the core of this boom is the growth of the tar sands. It is simply not credible to treat the output of the great tar sands' boom as being in the same category as, say, the fish, fur and lumber identified by Harold Innis' as the first key staples in the development of the modern Canadian economy (Innis, 1962: 401-2). Tar sands production is capitalintensive industrial production on a vast scale. Alfred J. Cavallo (2005: 16-18) makes this point very clearly in The Bulletin of the Atomic Scientists.

Tar sands are of a completely different character than conventional oil deposits; making tar sands usable is a capital-intensive venture that requires special procedures such as heating to separate the tar from the sand, mixing the tar with a diluting agent for pipeline transport, and constructing specially equipped refineries for processing.

This is certainly a description of an industry that is extremely environmentally destructive. But as a capital-intensive industrial activity, it has nothing in common with the earlier staples analyzed in the classic texts of Canadian political economy. We had best become accustomed to interrogating these categories in ways appropriate to the 21 st century. In the desperate search for new sources of oil, tar sands will soon be joined by their distant cousin, shale.

Extracting oil from the 3 trillion barrels of oil shale ... presents its own challenges. The term "oil shale" is also quite misleading, since there is no oil in this mineral, but rather an organic material called kerogen, which is a precursor of petroleum. To extract oil, the shale (typically between 5 and 25 percent kerogen) must first be mined, then transported to a plant where it is crushed, then heated to 500 degrees Celsius, which pyrolyzes, or decomposes, the kerogen to form oil (Cavallo, 2005: 16-18).

The use of tar sands and shale to create energy may be signs of cultural decline, environmental destruction and short-sighted energy policies. But they are not signs of economic underdevelopment. The biggest shale deposits in the world are in the U.S. When they come onstream, and begin to show up in U.S. economic statistics, we would be welladvised to understand these statistics as representing manufacturing and industrial power, not manufacturing and industrial decline. 


\section{Of Nails and Needles: A Reconsideration of the \\ Political Economy of Canadian Trade}

\section{Conclusion}

Canada has had a more or less developed home market economy since the latter half of the 19 th century. ${ }^{5}$ That is not to say that Canada can survive solely on the basis of its home market. As one of the most trade dependent economies in the world, Canada clearly needs access to markets far beyond its borders. What it does mean, though is that Canada has been the beneficiary of what Marx called the accumulation and reproduction of capital on an extended scale (Marx, 1986; 80-83). This term is developed in the least read, and maybe the most important of Marx's three-volume anatomy of the capitalist system. There are two ways of reading this text. One is to focus on the important argument about the 'selfexpansion of value'. But the other is to use this notion in the context of the world economy, and query the direction of this self-expansion. The very economic basis of imperialism is to ensure that the self-expansion of capital flows in the direction of the imperial centre, frustrating the development of the periphery. Nominal political sovereignty can be compatible with the continuation of an imperialist system, unless it is accompanied by a parallel assertion of economic sovereignty, redirecting the self-expansion of value away from the centre and toward the periphery. ${ }^{6}$

This is a fundamentally important point. It is the reason why an oil state like Alberta has a fantastically different economic profile from an oil state like Venezuela. The former is part of an advanced capitalist economy with a well-established home market economy. The latter has had the development of such an economy frustrated by generations of imperialist economic domination. It is why debates over Canada's place in the world economy matter. Whether Canada is part of the world system which benefits from the domination of other economies, or is an economy which suffers from domination is, in a certain sense, the first question which any political economist has to answer. Hopefully this article has made some contribution to this ongoing discussion.

5 A point made very persuasively by H. Clare Pentland (1981). For a contemporary restatement, see Kellogg (2005a). From a political economy standpoint, Canada's emergence as an independent state in 1867 is coincident with, and dependent on this emergence of a self-sustaining home market economy.

6 For evidence of this conflict unfolding in the current reality, a study of the confrontation between Bolivia, Venezuela and Ecuador and the foreign energy multinationals which operate on their soil, would be a good starting point. 


\section{Of Nails and Needles: A Reconsideration of the \\ Political Economy of Canadian Trade}

\section{REFERENCES}

Aerospace and Automotive Branch, Industry Canada. "Statistical Review of the Canadian Automotive Industry: 2001 Edition.” August. <http://dsp-psd.pwgsc.gc.ca/Collection/ C25-7-2001E.pdf $>$ (January 20, 2008).

Anastakis, Dimitry. 2004. "Between Nationalism and Continentalism: State Auto Industry Policy and the Canadian UAW, 1960-1970." Labour/Le Travail, 53, Spring, pp. 89126.

Hofffman, Kathy Barks. 2005. "Ontario Eclipses Michigan in Auto Production." The Detroit News Auto Insider, July 16. <www.detnews.com/2005/autosinsider/0507/17/ autos-249603.htm> (January 20, 2008).

Brym, Robert (ed.). 1985. The Structure of the Canadian Capitalist Class. Toronto. Garamond Press.

Bureau of Labor Statistics, "Establishment Data: Historical Employment, Table B-1. Employees on Nonfarm Payrolls by Major Industry Sector, 1957 to date." <ftp://ftp. bls.gov/pub/suppl/empsit.ceseeb1.txt> (January 20, 2008).

CANSIM (Canadian Socioeconomic Information Management) II. Table 228003, "Merchandise Imports and Exports, by Major Groups and Principal Trading Areas for All Countries.” January 20, 2008.

CANSIM II. Table 2820011, "Labour Force Survey Estimates (LFS), Employment by Class of Worker, North American Industry Classification System (NAICS) and Sex."

Carroll, William. 1985. "Dependency, Imperialism and the Capitalist Class in Canada." In The Structure of the Canadian Capitalist Class. Robert J. Brym (ed.). Toronto: Garamond Press, pp. 21-52.

Cavallo, Alfred J. 2005. "Oil: Caveat Empty." Bulletin of the Atomic Scientists. May/Jun, Vol. 61, No. 03.

Clement, Wallace (ed.). 1997. Understanding Canada: Building on the New Canadian Political Economy. Kingston. McGill-Queen's University Press.

Clement, Wallace and Drache, Daniel (eds.). 1978. A Practical Guide to Canadian Political Economy. Toronto: James Lorimer \& Company. 


\section{Of Nails and Needles: A Reconsideration of the \\ Political Economy of Canadian Trade}

Clement, Wallace and Williams, Glen. 1997. "Resources and Manufacturing in Canada's Political Economy. In Understanding Canada: Building on the New Canadian Political Economy. Wallace Clement (ed.). Kingston: McGill-Queen's University Press, pp. 43-63.

Clement, Wallace and Vosko, Leah (eds.). 2003. Changing Canada: Political Economy as Transformation. Kingston: McGill-Queen's University Press.

Cross, Michael and Kealey, Gregory (eds.). 1984. Modern Canada 1930-1980's. Toronto: McClelland and Stewart.

Dominion Bureau of Statistics, External Trade Branch. January 1947, December 19471961. "Trade of Canada, Domestic Exports." Ottawa: Minister of Trade and Commerce. Catalogue 65-002.

Dominion Bureau of Statistics, External Trade Branch. January 1962, December 19651971. "Summary of Exports". Ottawa: Minister of Industry, Trade and Commerce. Catalogue 65-002.

Dominion Bureau of Statistics, International Trade Division, External Trade Section. 1961. "Trade of Canada: Export Commodity Classification" Working Document. January 1. Ottawa: Minister of Trade and Commerce. Catalogue 15-521. Microform.

Drache, Daniel and Clement, Wallace (eds.). 1985. The New Practical Guide to Canadian Political Economy. Toronto. James Lorimer \& Company.

Gindin, Sam. 2007. "The CAW and Magna: What if Magna Builds an Assembly Plant?" The Bullet, Socialist Project E-Bulletin No. 71, November. <www.socialistproject. ca/bullet/bullet071.html> (January 20, 2008).

Innis, Harold. 1962. The Fur Trade in Canada. Toronto: University of Toronto Press.

International Organization of Motor Vehicle Manufacturers, "Industry Statistics, Car production (per capita) (most recent) by country." Compiled at Nationmaster.com. $<$ www.nationmaster.com/graph/ind_car_pro_percap-industry-car-production-percapita\#source> (January 20, 2008).

Kellogg, Paul. 1991. “Arms and the Nation: The Impact of 'Military Parasitism' on Canada's Place in the World Economy.” Ph.D. dissertation. Kingston: Queen's University, Dept. of Political Studies. 


\section{Of Nails and Needles: A Reconsideration of the \\ Political Economy of Canadian Trade}

Kellogg, Paul. 2003. "After Left Nationalism: The Future of Canadian Political Economy," paper presented to the conference of the Canadian Political Science Association. Halifax: Dalhousie University.

Kellogg, Paul. 2004. "After Left Nationalism: The Future of Canadian Political Economy." Marxism No. 2, 2004: A World to Win, pp. 21-31.

Kellogg, Paul. 2005a. "A Reconsideration of the Political Economy of Canadian Trade, Part I: Escape from the Staple Trap." Paper presented to the conference of the Canadian Political Science Association (Political Economy). London: University of Western Ontario.

Kellogg, Paul. 2005b. "Kari Levitt and the Long Detour of Canadian Political Economy," Studies in Political Economy 76, Autumn, p. 31-60.

Leacy, F.H. (ed.). 1982. Historical Statistics of Canada Second Edition. Ottawa: Statistics Canada.

Macdonald, Donald S. et. al. (eds.). 1985. Report of the Royal Commission on the Economic Union and Development Prospects for Canada, volume I. Ottawa: Minister of Supply and Services (usually referred to simply as The Macdonald Report).

Maizels, Alfred. 1963. Industrial Growth and World Trade. Cambridge: Cambridge University Press.

Marx, Karl. 1986. Capital Volume II. Moscow: Progress Publishers.

McNally, David. 1981. "Staple Theory as Commodity Fetishism: Marx, Innis and Canadian Political Economy.” Studies in Political Economy, 6, Autumn, pp. 35-64.

Ministry of Economic Development and Trade. 2003. "Business and Investment Bulletin." Volume 6, Issue 1, Winter. <www.2ontario.com/software/newsletters/newsletter vol6_issue1.asp $>$ (January 20, 2008).

Pentland, H. Clare. 1981. Labour and Capital in Canada: Canada 1650-1860. Toronto: James Lorimer \& Company.

Stanford, Jim, 2007. "Hewer of wood, pumper of oil." In The Toronto Star, January 2, p. A13. 
Statistics Canada, External Trade Division. December 1974. "Trade of Canada, Summary of Exports". Ottawa: Minister of Industry Trade and Commerce. Catalogue 12-521.

Statistics Canada, External Trade Division. December 1975-1984. "Trade of Canada, Summary of External Trade". Ottawa: Minister of Industry Trade and Commerce. Catalogue 12-521.

Statistics Canada, International Trade Division. December 1986-1988. "Summary of Canadian International Trade". Ottawa: Minister of Supply and Services. Catalogue 65-001.

Statistics Canada. January 1988. "Preliminary Statement of Canadian International Trade". Ottawa: Minister of Industry Trade and Commerce. Catalogue 65-001P.

United Nations Statistics Division. "National Accounts: Estimates of Value Added and Selected Components at constant 1990 prices in Million U.S. Dollars." <http://unstats. un.org/unsd/snaama/selectionbasicFast.asp> (January 20, 2008)

U.S. Census Bureau, International Data Base. "Table 001: Total Midyear Population. $<$ www.census.gov/cgi-bin/ipc/idbsprd $>$ (January 20, 2008).

Williams, Glen. 1986. Not For Export: Toward a Political Economy of Canada's Arrested Industrialization. Toronto: McClelland and Stewart.

Williams, Glen, 1988. "On Determining Canada's Location Within the International Political Economy." 1988. Studies in Political Economy, 25, Spring, pp. 107-140.

Williams, Glen. 1994. Not For Export: the International Competitiveness of Canadian Manufacturing. Toronto: McClelland \& Stewart. 